\title{
Groundwater Level Changes since 1978 in an African City on Basement Rocks: The Case of the CIEH Borehole in Ouagadougou (Burkina Faso)
}

\author{
Ali Houmadi Mouhouyouddine ${ }^{1,2}$, Suzanne Yameogo ${ }^{3}$, Pierre Genthon ${ }^{2 *}$, \\ Jean Emmanuel Paturel2 ${ }^{2}$, Maurice Guilliod² \\ ${ }^{1}$ University of Comoros, Moroni, Comoros \\ ${ }^{2}$ HydroSciences Montpellier, IRD, CNRS, University of Montpellier, Montpellier, France \\ ${ }^{3}$ Hydrogeology Laboratory, University of Ouagadougou, Ouagadougou, Burkina Faso \\ Email: alihoumadizaka@yahoo.com, *pierre.genthon@ird.fr, jean-emmanuel.paturel@ird.fr, maurice.guilliod@ird.fr, \\ suzanneyameogo@yahoo.fr
}

How to cite this paper: Mouhouyouddine, A.H., Yameogo, S., Genthon, P., Paturel, J.E. and Guilliod, M. (2017) Groundwater Level Changes since 1978 in an African City on Basement Rocks: The Case of the CIEH Borehole in Ouagadougou (Burkina Faso). Journal of Water Resource and Protection, 9, 1097-1118.

https://doi.org/10.4236/jwarp.2017.910072

Received: June 27, 2017

Accepted: September 12, 2017

Published: September 15, 2017

Copyright (c) 2017 by authors and Scientific Research Publishing Inc. This work is licensed under the Creative Commons Attribution International License (CC BY 4.0).

http://creativecommons.org/licenses/by/4.0/

\begin{abstract}
The CIEH piezometer, located in the center of Ouagadougou city presents a water level record spanning the West African Drought which peaked during the 80s and 90s. Its water level is investigated as a potential proxy for groundwater water resources in West African basement rock aquifers submitted to climate changes. 23 boreholes and wells in various land uses and within a 2 $\mathrm{km}$ radius around the CIEH piezometer were monitored during the 2013-2014 hydrologic year. The minimum water level occurred in May, at the end of the dry season, while the maximum took place in October, one month after the end of the rainy season. The mean water level amplitude is $3 \mathrm{~m}$, the minimum amplitude being reached at the $\mathrm{CIEH}$ piezometer $(0.76 \mathrm{~m})$. Moreover, the CIEH piezometer is located in a $2 \mathrm{~m}$ amplitude water table depression either in May or in October. Simplified $2 \mathrm{~d}$ modeling using a general basement aquifer structure shows that (i) the water level in the piezometer is under ongoing influence of the spillway raise of the nearby dam\#3 lake in 2002, (ii) the whole 1978-2004 period cannot be modelled with constant parameters. A 3\% decrease of water uptake is adopted after 1985, presumably resulting from land use changes in the Ouagadougou city. The water table at the CIEH piezometer is presently at its 1978 level, which can considered as a pre-drought value. However this includes a $1.5 \mathrm{~m}$ contribution of the two abovementioned anthropic effects Further quantitative interpretations of the CIEH piezometer record will require additional geophysical and hydrological investigations.
\end{abstract}




\section{Keywords}

Urban Groundwater, Climate Change, Crystalline Rocks, Africa, Burkina Faso

\section{Introduction}

Situated in the center of the Ouagadougou main city (Figure 1), the CIEH (Inter-African Comity for Hydraulic studies) piezometer presents a mostly continuous record starting in 1978. At our knowledge, this record is unique at the scale of the whole West Africa and therefore it deserves throughout analysis. This record spans a large part of the African Drought, which peaked between the 80 s and the 90s in the Sudanian and Sahelian zones of West and Central Africa, and is now considered as one of the most significant drought events worldwide [1] [2]. Moreover, Ouagadougou is situated on basement rocks where aquifers are fully included in the few tens of meter thick weathering profile [3] [4] [5].

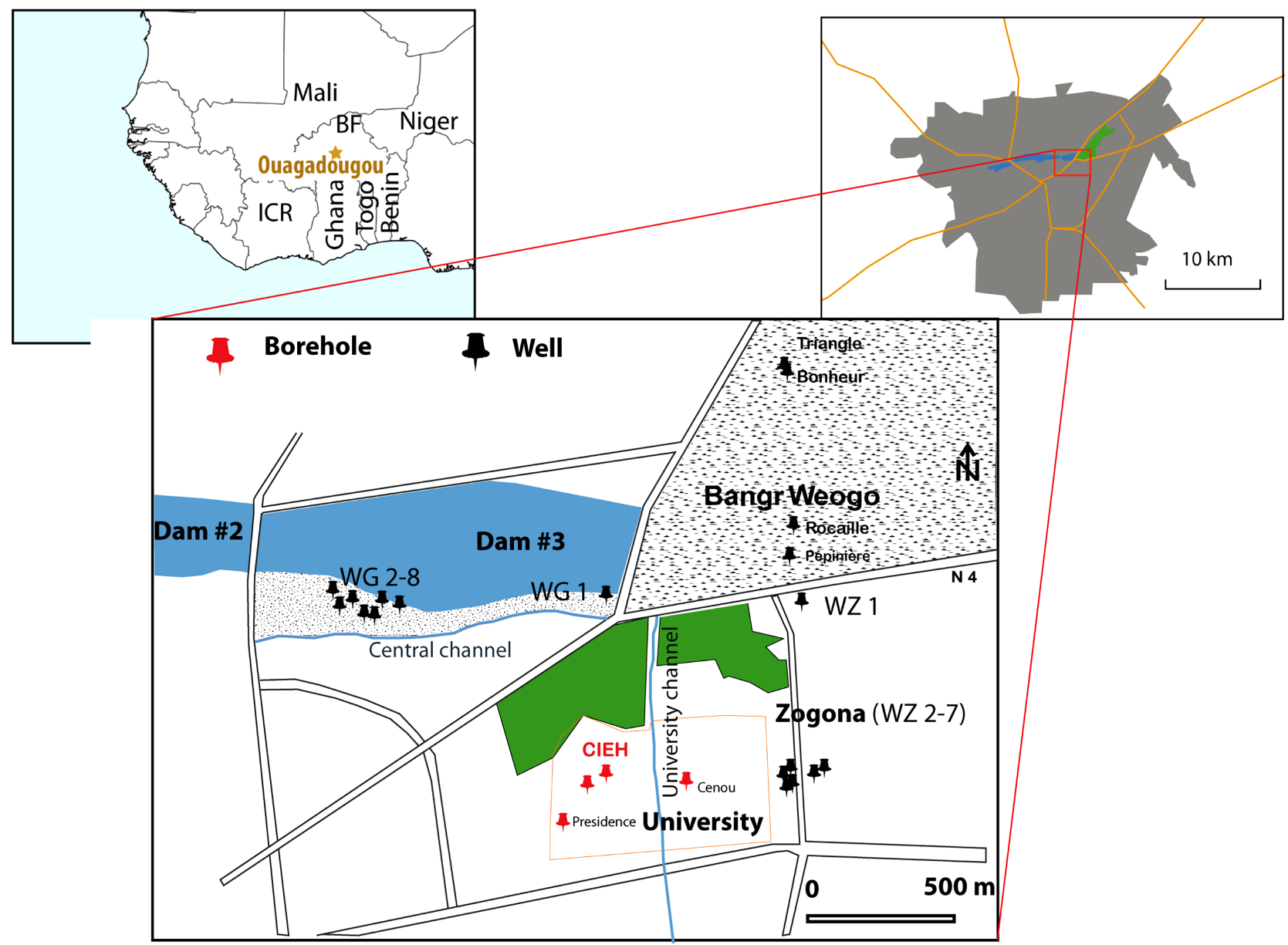

\section{Gardened area}

\section{Wetland} natural area Green
area
Urban

area

Figure 1. Outline of the study area. 
Therefore, the available groundwater resource is limited when compared to sedimentary aquifers [6] [7]. Moreover, basement aquifers are sensitive to climate events at any time scale larger than a few months [8]. 40\% of African people rely on basement aquifers for groundwater. Fast development of African cities-more than 7\% annual population growth in Ouagadougou [9] - results in increasing water demand and serious risks of water shortage [10]. In Ouagadougou, tap water comes from a series of dams, the main one-the Ziga dam-being located $50 \mathrm{~km}$ away from the city. However, due to combined silting and evaporation and due to the growth of the city, water shortage is planned in the few coming years and a complementary resource will be sought from boreholes. The water level record at the CIEH piezometer (P-CIEH), since it spans the duration of the African Drought, may help to assess the effect of climate changes on groundwater resources in Ouagadougou, and provide some general indications for African cities on basement rocks.

In order to better define the specificities of $\mathrm{P}$-CIEH, a piezometric network was set up on different land use sites around this borehole (Figure 1) and monitored during the 2013-2014 hydrologic year. The water level signal is firstly analyzed as a function of land use for the 2013-2014 hydrologic year and two water table maps are built for the highest (October) and lowest (May) water levels. Then, the signal observed at P-CIEH is analyzed as function of rainfall and a simplified $2 \mathrm{~d}$ model is used to check different mechanisms possibly controlling its water level. Finally, further investigations are suggested and possible generalization to West African basement aquifers is discussed.

\section{Study Area}

Ouagadougou is located near the center of Burkina Faso and the study area lies in the eastern part of the city center (Figure 1). It includes (i) an old urban area: the Zogona neighborhood, (ii) a part of the Ouagadougou University built from 1974, (iii) a protected forested recreational area, the Bangr Weogo Park (iv) a vegetable gardening area. This corresponds to contrasted land uses within the study area. This area is bordered to the north by a series of three reservoirs built in 1963 in the Nabaouli riverbed and that drain into the Bangr Weogo wetland. A large part of rainfall and sewage waters from the city of Ouagadougou are drained toward the Bangr Weogo wetland trough the Central and University concreted channels. The University channel was only an earth channel until 2004. Ouagadougou is located on Proterozoic granites and granodiorites [11] which are basement rocks and present specific properties.

\section{The Weathering Profile of Granitic Rocks and Its Relationship with Groundwater Resources}

Recent works allowed to define the relationship between weathering and aquifer properties [3] [12] [13] [14]. The weathering profile includes from top to bottom (i) fine saprolite which consists of the non-soluble part of the weathered initial 
rock including $\mathrm{Fe}$ and $\mathrm{Al}$ oxides (ii) coarse saprolite, including the previous minerals with clays (kaolinite, mainly) and in some instances quartz. The saprolite thickness is in the $10 \mathrm{~m}-30 \mathrm{~m}$ range in the study area [15]. The hydraulic conductivity of saprolites is low, near $10^{-6} \mathrm{~m} / \mathrm{s}$, their specific yield amounts to 1 $15 \%$ [16]. A specific yield ranging between $1 \%$ and $5 \%$ is proposed in the central Burkina Faso [17], a 0.5\% - 5\% range results from aquifer tests on the nearby Sanon site [18], while a $5 \%$ mean value is proposed in the Ouagadougou city [15] [19]. In some instances, the base of the saprolitic layer includes a few meters thick arenic layer of high hydraulic conductivity [3]. However this layer is absent or it contains a high proportion of clay in Ouagadougou [20]. Below the saprolitic layer, granite presents horizontal fissures with an extension ranging from 3 to $40 \mathrm{~m}$ which produce a hydraulic conductivity of the order of magnitude of $10^{-5} \mathrm{~m} / \mathrm{s}$ and allow to drain water included in the saprolitic layer [21] [22]. Within this layer, both the density of horizontal fissures and their aperture decrease with depth. Recognition of this fissured layer as part of the weathering profile [16] and of its role in the basement aquifer drainage constitute a significant and recent advance for water resource management of basement rocks aquifers [5].

\section{Material and Methods}

\subsection{Climatic Data}

Rainfall data at the Ouagadougou airport are available for the 1953-2010 period. After 2010, we use data from the IRD raingauge after having checked on overlapping periods that rainfall measured there was close to that of the Ouagadougou airport. Daily temperatures, potential evaporation rates and relative humidity for the 1978-2009 period were measured at the Ouagadougou airport.

\subsection{The Piezometric Network}

One of the longest piezometric record in West Africa is available for the CIEH (African Comity of Hydraulic studies) piezometer since 1978, with some missing data, especially during the $90 \mathrm{~s}$. A local piezometric network was monitored during the 2013-2014 hydrologic year (June 2013 - June 2014). It includes 29 wells and boreholes less than $2 \mathrm{~km}$ away from P-CIEH and located in contrasted land uses (Figure 1). Four boreholes were drilled in the University of Ouagadougou to provide drinking water and are no more used since tap water is available (near 1990). Logging information of these boreholes is no more available. It is reported [23] that P-CIEH was drilled down to a $20 \mathrm{~m}$ depth, was screened from 6 $\mathrm{m}$ to $20 \mathrm{~m}$ and that within this depth interval the borehole intersected $5 \mathrm{~m}$ of granitic sand, $4 \mathrm{~m}$ of weathered granite and $5 \mathrm{~m}$ of fresh granite. New buildings were set up within a $100 \mathrm{~m}$ radius of P-CIEH in 1975 and 1999 with local infiltration of rain falling on their roofs. For the two last buildings constructed in 2006 rainfall is stored for later lawn watering. Original vegetation was removed and replaced by ornamental shrubs and trees and there are no asphalted areas in 
the surrounding of P-CIEH. The combined effects of those land use changes on the hydrologic budget cannot be assessed a priori.

Other boreholes were drilled down to fresh basement. No aquifer tests results are available, except for P-CIEH, for which an unsuccessful pumping test was reported (flow rate less than $1 \mathrm{~m}^{3} / \mathrm{h}$ ). 18 wells were drilled by the FAO of UN immediately south of the dam\#3 lake to promote irrigated gardening and 5 additional wells were drilled by individual gardeners. However several of them are flooded during the rainy season and cannot be accessed. Therefore, a monthly record was only available for 8 wells in the gardening area. The water level recorded in these wells should be considered with care since they are used for manual irrigation and are situated close to temporarily flooded areas. 7 wells were monitored in the Zogona settlement. They are located in private properties and are used mostly for shower and laundry according to their owners. One of them is also used for drinking water, although such use is not recommended due to quality issues, especially during the rainy season [15]. One of them receives rainwater from the roof of the owner's house. The Bangr Weogo park receives rainwater and wastewater from the Ouagadougou city through the Central and University channels and from the dam\#3 spillway. It includes several wetland areas, especially during the rainy season. A series of wells were drilled recently for irrigation during the dry season but are not used presently and therefore they constitute reliable piezometers. They were drilled nearly one meter below the water level of the dry season. One well is located in a tree nursery with daily watering during the dry season. Two wells are $30 \mathrm{~m}$ apart. The first one (Triangle well) was considered as unsuccessful since it was dry at the time of drilling. Only the second one (Bonheur well) is used for defining the water table. Geological material extracted during drilling is still visible around the wells and exhibit coarse saprolites keeping shapes of the original granitic material. Complete monthly record during the 2013-2014 hydrologic year is only available for 19 wells and 4 boreholes. Water table maps were built using the topographic map published in 1984 by the National Geographical Institute of Burkina Faso (IGB) as a reference. Topography is gently dipping toward the east-west trending low zone constituted by the three reservoirs and the Bangr Weogo wetland. Level curves of this map were digitized and the elevation of wells and boreholes of the network were interpolated from these data. Since the contouring interval is $5 \mathrm{~m}$, only a few meters accuracy can be expected. Leveling data with an accuracy of 5 $\mathrm{cm}$ were also available for boreholes in the University area and the level gauge of the dam\#3 lake as well as a topographic map resulting from optical leveling for the Bangr Weogo park [24]. A constant elevation offset was considered between the IGB 1984 map and these local data.

\subsection{Water Level at the Dam\#3 Lake}

Three reservoirs were built in 1963 in the Nabaouli riverbed to provide drinking water for the Ouagadougou city. Only the third one-the dam\#3 lake-is pre- 
sently used as a minor supply. Water level data are available for this water body between 1979 and 2009.

\subsection{Groundwater Models}

The GARDENIA 1d three reservoirs model [25] and the MOFLOW96 2d model [26] [27] are used in the present study.

\section{Data Analysis}

\subsection{Rainfall}

Rainfall is governed by the African monsoon. October to April are almost dry months. Starting in mid-April a southwestern wind sets up and brings wet air from the Atlantic ocean. The rainy season begins between May and June, peaks in July and August and ends near mid-September (Figure 2). Annual rainfall present large variability (Figure 3) with a mean value of $780 \mathrm{~mm}$ between 1953 and 2013, and $1040 \mathrm{~mm}$ and $730 \mathrm{~mm}$ in 2012 and 2013. Figure 3 shows that the African Drought was characterized in Ouagadougou by the lack of wet years such as those recorded previously during the 60 s and 70 s and by some extremely dry years (rainfall $<550 \mathrm{~mm}$ ). Partial recovery in rainfall is observed since the 2000 s with the return of some annual rainfalls exceeding $850 \mathrm{~mm}$.

\subsection{Temperature, Potential Evapotranspiration (PE), Humidity}

These data are provided in Figure 4 as monthly averaged values. Temperature is controlled by the season and by rainfall. Minimum temperature occurs in January. It increases until April, when the maximum daily temperature currently exceeds $40^{\circ} \mathrm{C}$, is buffered by evaporation during the rainy season, and increases again temporarily after rain stops in October. Relative humidity is controlled by

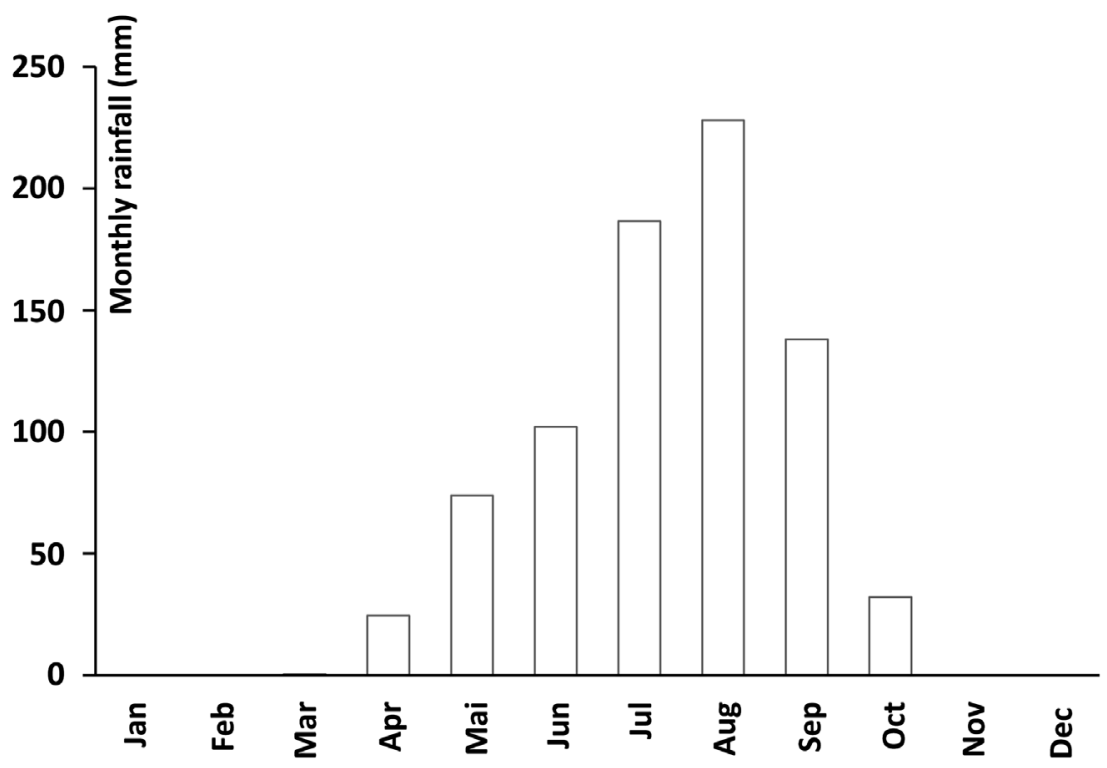

Figure 2. 1978-2013 mean monthly rainfall in Ouagadougou. 


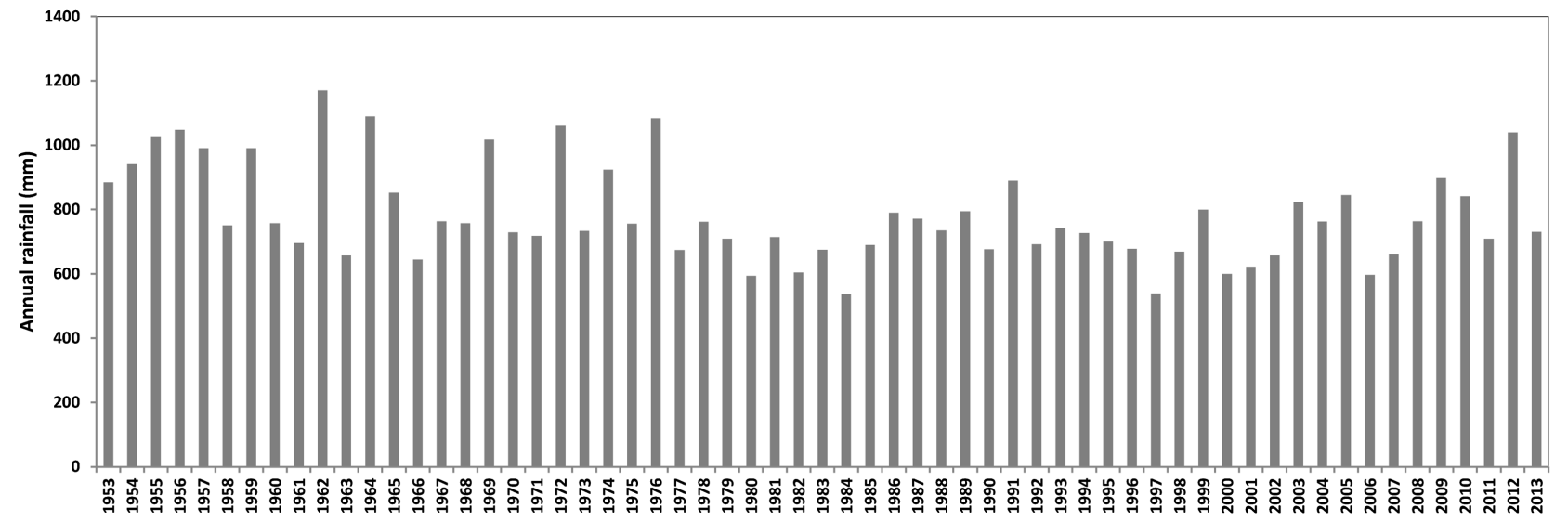

Figure 3. Annual rainfall in Ouagadougou.

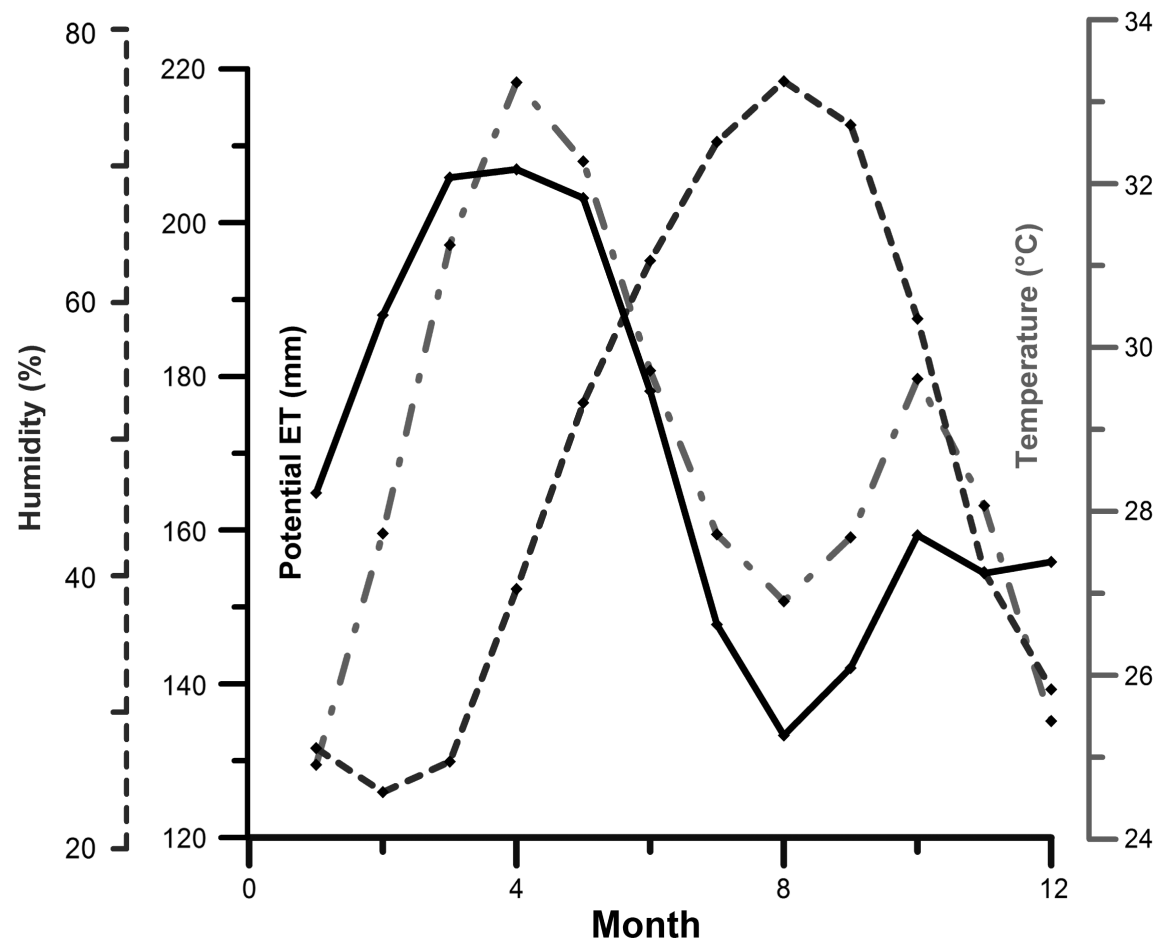

Figure 4. Mean monthly temperature, PE and relative humidity in Ouagadougou (1978-2009 average).

rainfall, and PE depends both from humidity and temperature. Maximum PE occurs in April, because of both the maximal temperature and minimal humidity; PE decreases during the rainy season due to the decrease of temperature and increase of humidity and increases again, with a slight secondary maximum in October.

\subsection{Water Level}

\subsubsection{Water Level Fluctuations during the 2013-2014 Year}

In 2013, major rainfalls began at the end of May just after the setup of the network (Figure 5). The gardening area was partly flooded and several wells (not 

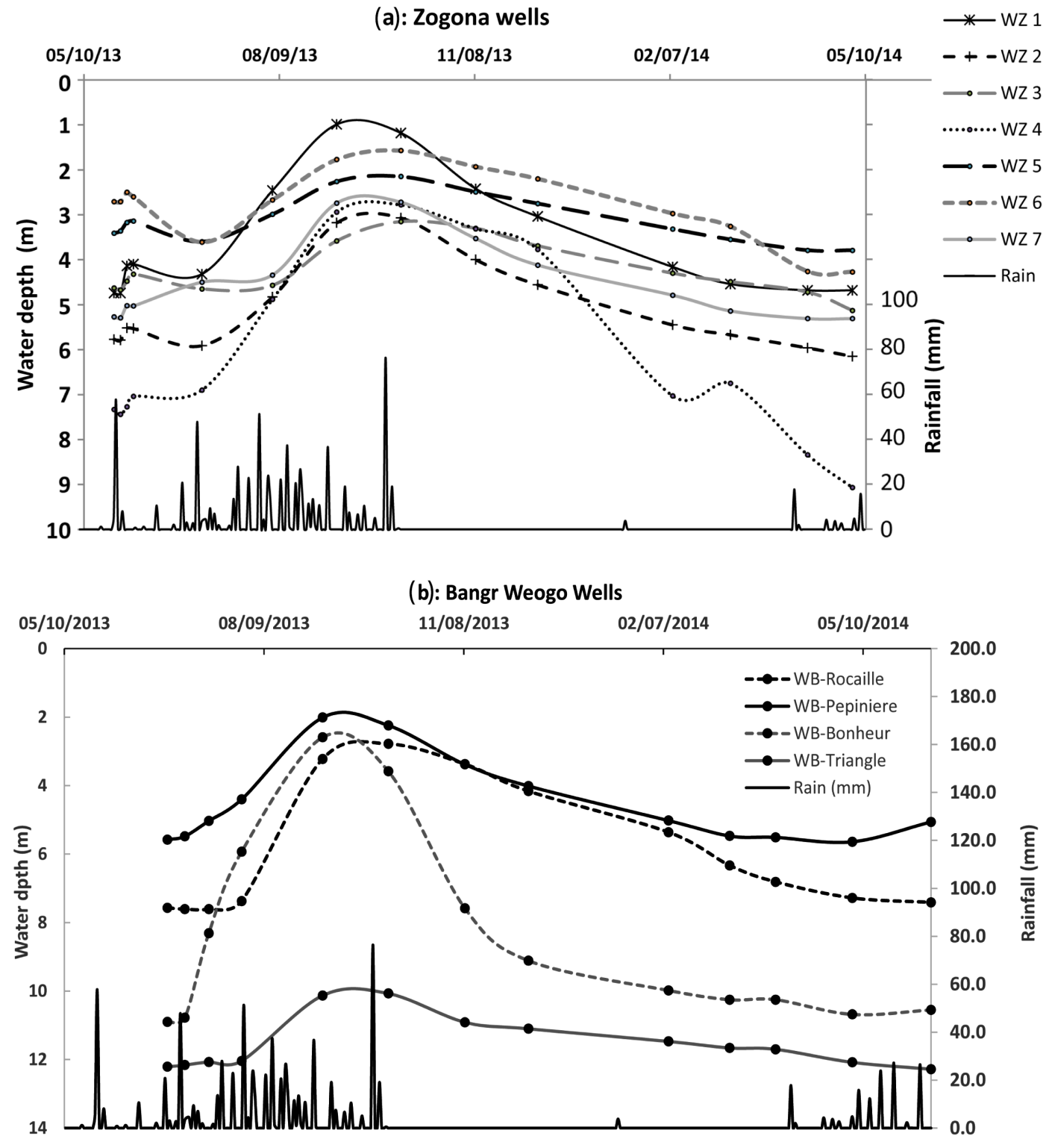

(c): University area

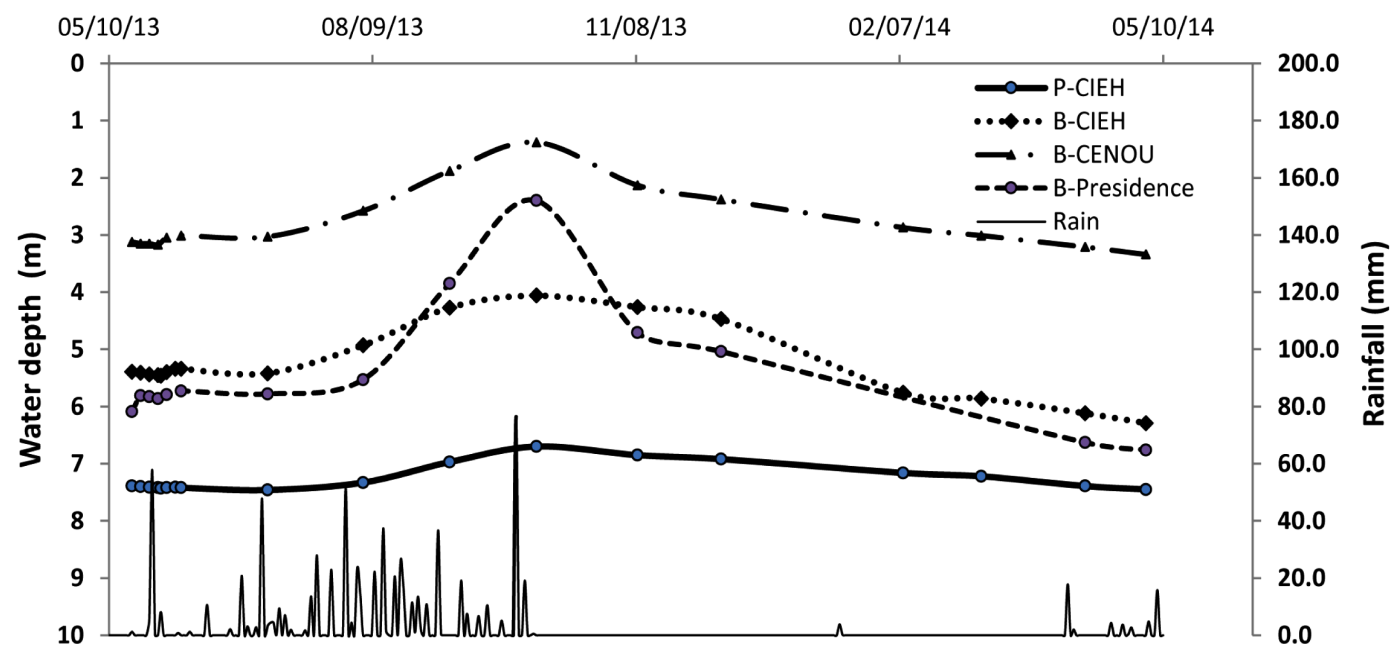




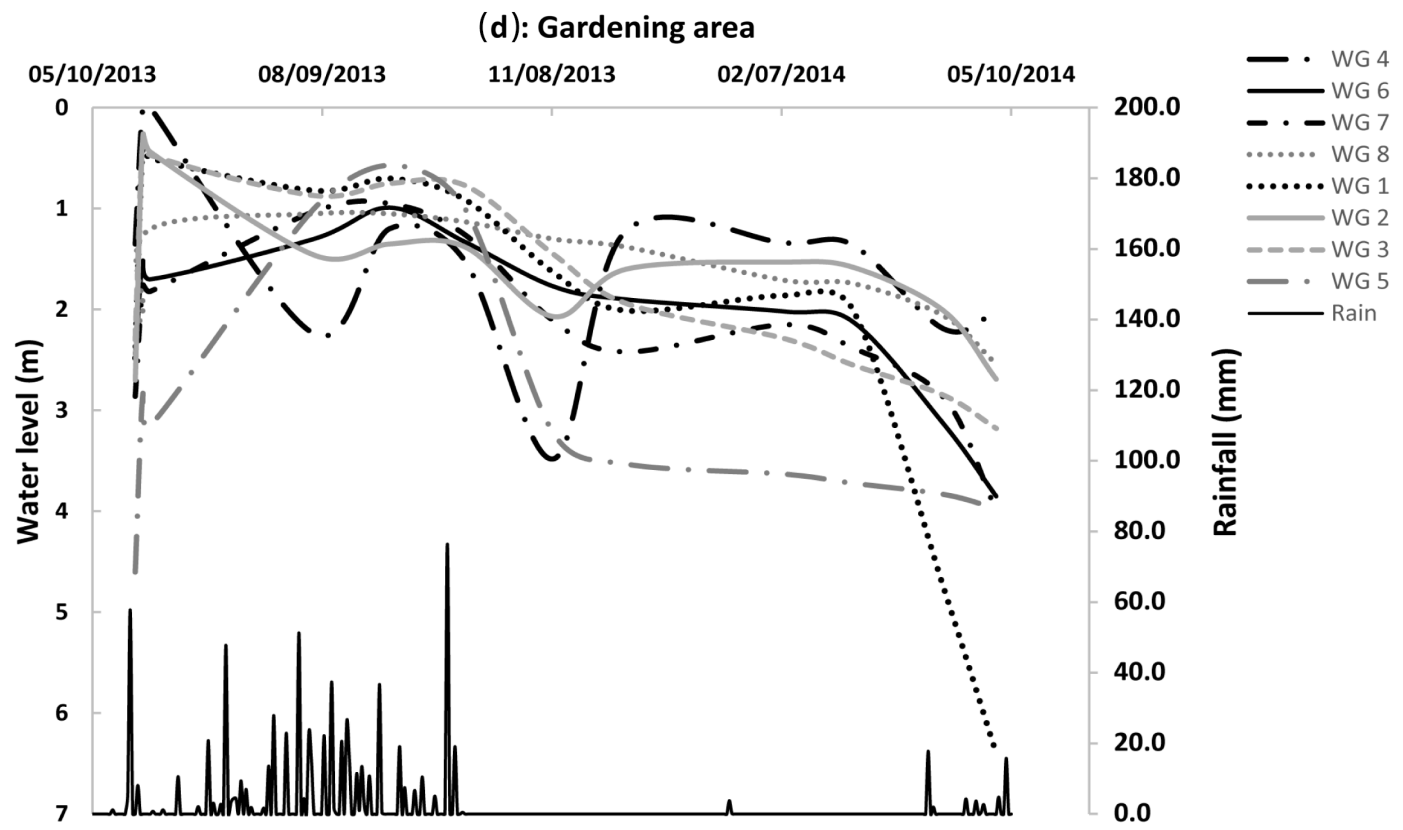

Figure 5. Water level during the 2013-2014 year in the four zones of the study area. The vertical scale is different in each sub-figure. Moreover, due to offsets in the onset of the records, the time scale in (a), (c) and (d) spans the [05/10/13 - 05/10/14] time period while in (b) it spans the [06/26/13-06/26/14] period.

shown here) could not be accessed. The general trend in the network consists of a slow rise and a maximum water level reached in September or October, at the end of the rainy season followed by a steady decrease of the water level until June. In the Zogona area (Figure 5(a)), the WZ7 well where the water level rises immediately after the rainy event at the end of May is located near a low area which is ponded after each heavy rain. Similarly in the Bangr Weogo area (Figure 5(b)) the Pepiniere well is located in a tree nursery area, which is irrigated daily during the dry season. Therefore, it can be suspected that high water content in the vadose zone explains the immediate rise of the water level after rain. Further north, there is strong contrast between the Triangle and Bonheur wells (Figure 5(b)) although they are only $30 \mathrm{~m}$ apart from each other and located close to a swampy zone flooded during the rainy season. The water level in the Triangle well is $1 \mathrm{~m}$ to $2 \mathrm{~m}$ lower than in the Bonheur well during the dry season and up $8 \mathrm{~m}$ lower at the end of the rainy season. The water level gradient between the Bonheur and Triangle wells reaches 0.25 in October, which can only be sustained by an impervious material. This impervious material around the Triangle well may explain why it was considered as a dry well after drilling. In the University area (Figure $5(\mathrm{c})$ ) there is also a nearly $2 \mathrm{~m}$ water level difference between the $\mathrm{CIEH}$ piezometer (P-CIEH) and borehole (B-CIEH) although they are $100 \mathrm{~m}$ apart from each other and located on a flat area.

Moreover, the water level amplitude at B-CIEH is three times the one at $\mathrm{P}$-CIEH. The case of wells located in the gardening area (Figure 5(d)) is complex due to flooding and to water withdrawal for irrigation. All wells of this area reacted in less than one week to the rainy event of May 24, 2013 by a several me- 
ter rise of the water level. In most wells, the water level dropped before a second increase until the end of the rainy season. The local minimum observed on some wells in November as well as the strong water level decrease starting in March are probably linked to the water demand of crops.

It was found that at the scale of the whole crystalline Burkina Faso, the amplitude of water level fluctuations was decreasing with increasing mean water depth, which corresponds to damping of the yearly signal during its downward propagation [28]. Such a study is not possible with the present dataset due to the limited duration of the record. As a simplified approach, we explore the relation between the minimum water level, considered as being reached in May 2013, and the difference with the maximum water level in October, considered as an approximation for the water level amplitude.

\subsubsection{Water Table Maps}

Two maps (Figure 6) were derived from 22 wells and boreholes at low water (May 2014) and near the maximum water level (October 2013). They share common features: (i) the dam\#3 lake surface lies above the aquifer on both maps. Therefore the lake recharges the aquifer throughout the year. This is not the case at the scale of the city of Ouagadougou and its surroundings where the water table follows the topography and dips toward the E-W minimum axis constituted by the 3 reservoirs in Ouagadougou [29]. (ii) Water levels in wells from the gardening area and from the Zogona neighborhood present strong local contrasts in May-probably due to differences in water extraction during the dry season-and a smoother water table at the end of the rainy season. The Bangr Weogo area corresponds to a pronounced depression in the water table, due to its location in the same topographic minimum as the three reservoirs and to a larger ET in this woody area. It should be noted that the Triangle well, which would have produced a strong discontinuity was discarded for the water table maps. (iii) The area near P-CIEH and the B-CIEH corresponds to a local piezometric depression. The northward extension of this depression is not defined due to the lack of data in this area, however the depression zone is defined by the contrast between both P-CIEH and B-CIEH and the two boreholes further south. The maps displayed in Figure 6 allow better understanding the trend observed on Figure 7. For the Zogona and gardening areas (minimum water level $<6 \mathrm{~m}$ ), there is strong water extraction at the end of the dry season and this extraction depends from an heterogeneous local demand. This induces strong water level gradients. Extraction stops during the rainy season since water is available in soils and in ponds. Then, smoothing of lateral piezometric gradients between nearby wells produces a flat water table. For the Bangr Weogo wells, the evapotranspiration from shrubs and trees is extracted during the dry season from deep soil since the upper soil layers are dry. This could explain the water level depletion at the end of the dry season. During the rainy season, vegetation is able to extract water from the upper soil layers allowing the aquifer to recover from the over-extraction during the dry season. The Pepiniere well where irrigation 

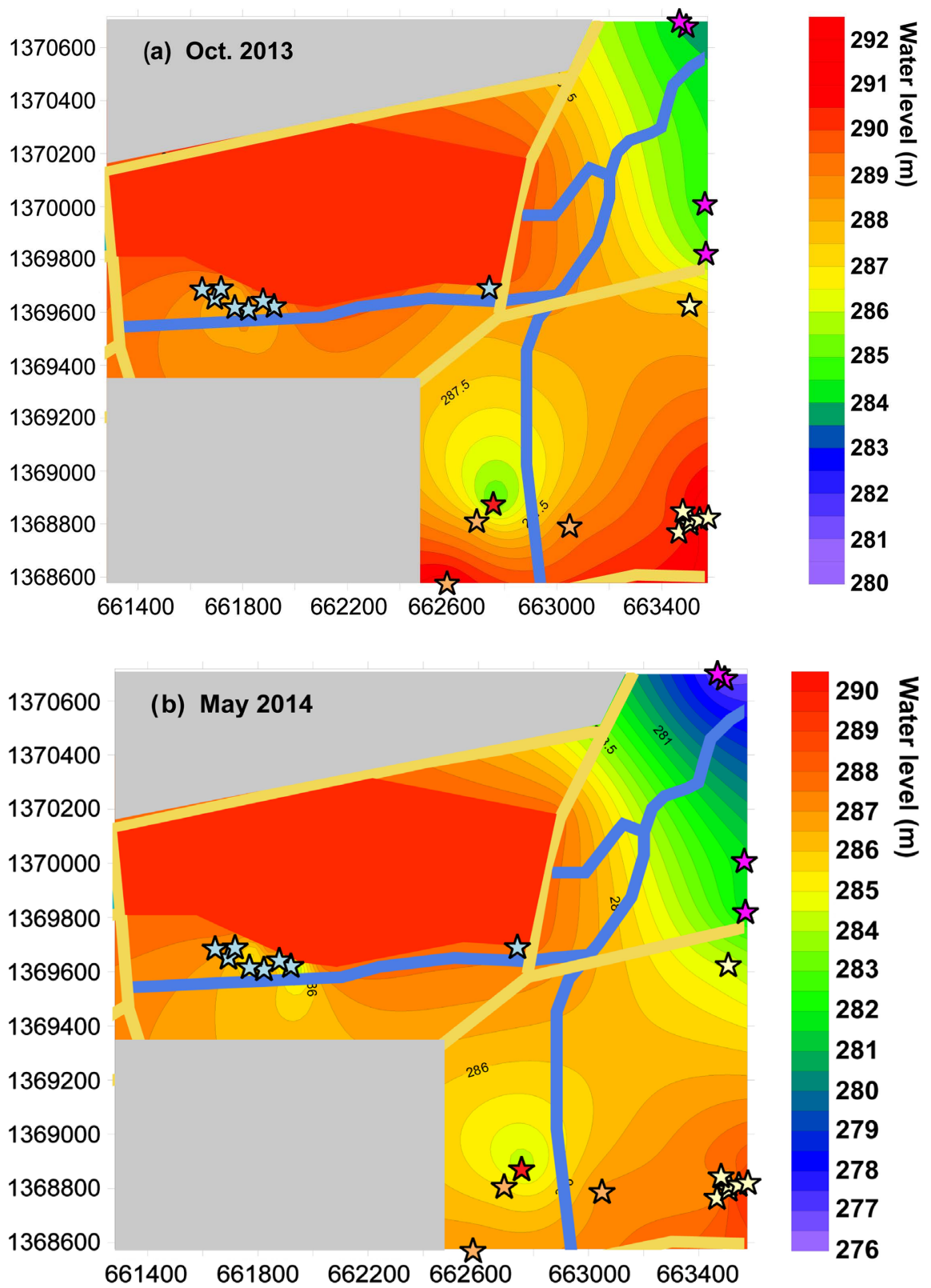

Figure 6. Water table maps of the study area. (a): high water level (Oct. 2013); (b): low water level (May 2014). Greyed areas correspond to insufficient data coverage and lengths at the left side and at the bottom of the maps are in meters (local Lambert projection).

is provided by tap water corresponds to the lowest depletion, while the Bonheur well corresponds to the largest amplitude due to strong depletion and to strong recharge due to its proximity with an area flooded during the rainy season. P-CIEH and the Triangle well lie well below the straight line defined in Figure 7, i.e. they correspond to both a lower minimum level and amplitude. We propose that they both lie in a low hydraulic conductivity area which prevents recharge either by rainwater or by lateral flow from nearby areas.

Recharge by infiltration from the dam\#3 lake was questioned by computing the characteristic distance [30] to which a perturbation of pulsation $\omega$ arising 


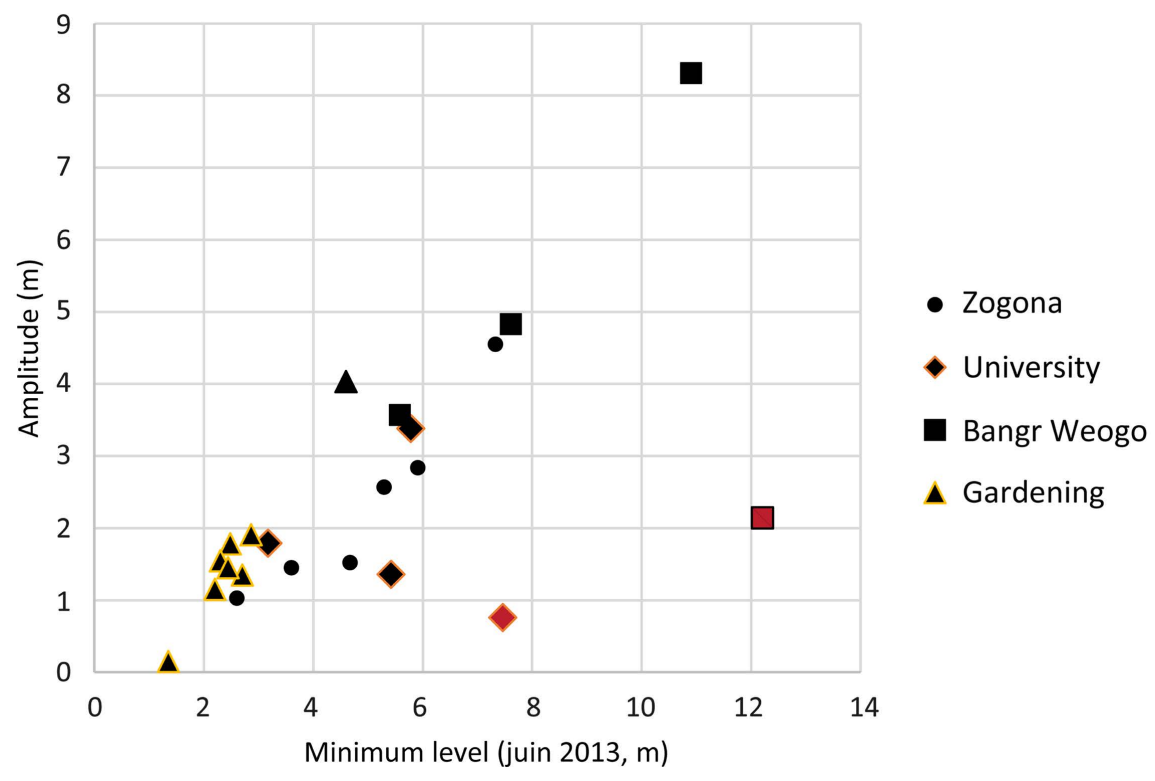

Figure 7. Relationship between the water level amplitude and the minimum water level in the piezometric network. The two symbols filled in red and situated below the general trend correspond to P-CIEH (diamond) and to the Triangle well (square).

from seasonal lake level changes could propagate inside an aquifer of transmissivity $T$ and specific yield $\phi$, which is:

$$
L=\left[\frac{2 T}{\omega \phi}\right]^{\frac{1}{2}}
$$

The yearly recharge corresponds to $\omega=2 \times 10^{-7} \mathrm{~s}^{-1}$. Then, assuming that transmissivity is controlled by a $10 \mathrm{~m}$ thick fissured layer of hydraulic conductivity $10^{-5} \mathrm{~m} / \mathrm{s}$ at the base of the weathering profile [4] $\mathrm{T}$ can be approximated by $10^{-4} \mathrm{~m} / \mathrm{s}$. Assuming in addition a specific yield of 5\% [15] and a two order of magnitude uncertainty on the $T / \phi$ ratio, $L$ is within the [45 - 450] $\mathrm{m}$ range, which implies that only wells in the gardening area are controlled by water level in the dam\#3 lake. However, when a time period of $60 \mathrm{yrs}$ is assumed for the Sahelian drought, $L$ is within the [350 - 3500] $\mathrm{m}$ range which implies that the whole network is submitted to the influence of the dam\#3 lake water level fluctuations at the $60 \mathrm{yrs}$ time scale.

During the 2013-2014 hydrologic year, and except for the gardening area where the water table is table is shallow and mainly controlled by the water level at the dam\#3 lake, both the water level amplitude and water table depth seem to be controlled by local differences in a given land use rather than systematic differences in the hydrologic cycle between the different land uses.

\subsubsection{Water Level Fluctuations at the Dam\#3 Lake}

Water level in this reservoir (Figure 8) is governed by rainfall and evaporation. The reservoir is filled up to the spillway level at the beginning of the rainy season and empties during the dry season due to evaporation. The water level drop stops when a significant rain event occurs during the dry season, which mainly 


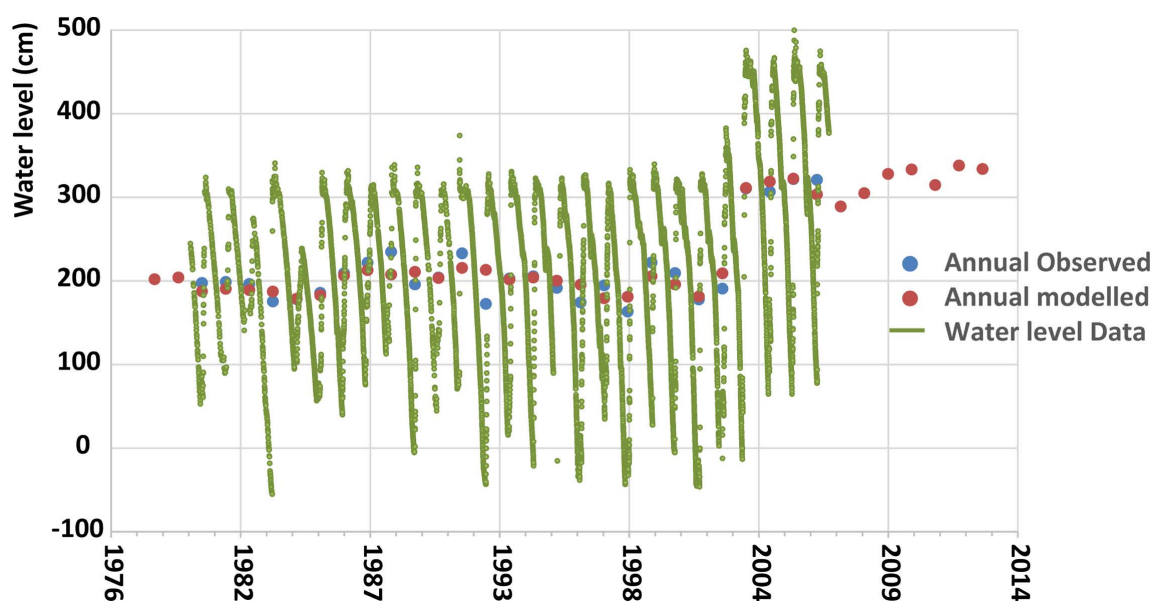

Figure 8. Water level and mean annual water level at the dam\#3 lake. The $400 \mathrm{~cm}$ level is $1.65 \mathrm{~m}$ below the reference level of P-CIEH.

occurs during wettest years. The spillway level is reached every year except during the 1982 and 1984 years, which were both extremely dry years. The $1.2 \mathrm{~m}$ rise of the maximum water level between 2000 and 2002 correspond to an heightening of the spillway. The mean annual water level was computed for each year (blue dots on Figure 8) using interpolation of existing data at a daily period. The main origin of long term water level variability in the third reservoir is the heightening of the spillway. Apart from this effect the mean water level lies within the narrow range corresponding to a $[160-235] \mathrm{cm}$ water level before the spillway heightening. A regression of the mean annual water was computed (red dots on Figure 8) as function of rainfall of the year and of the previous year and of an index rising slowly between zero and $1.2 \mathrm{~m}$ between 2000 and 2002 and which mimic the heightening of the spillway. This allows extrapolating the mean water level for missing years, before 1979 and after 2006. As seen in the previous paragraph, the piezometric level in the study area will be only sensitive to the mean water level outside a narrow band near the reservoir.

\subsubsection{The CIEH Piezometric Record}

This record (Figure 9) shows annual variations, with amplitude commensurate with annual rainfall, superposed to a pluriannual trend associated to the pluriannual rainfall trend. The water level decreases between 1978 and 1986, displays a complete oscillation between 1986 and 2002 and increases again after 2002.

\subsubsection{Correlation Analysis}

In order to assess the relationship between the water level at $\mathrm{P}$-CIEH and annual rainfall, a correlation analysis was carried out, starting from both the annual amplitude and the mean annual piezometric level. Due to the large amount of missing data the mean piezometric level is not computed but estimated visually. There is strong correlation (0.75) between the annual rainfall and the annual amplitude between 1978 and 1994. After 1994, the correlation weakens (0.62) 
and the computation is less stable due to the large proportion of missing data. The regression line of Figure 10 presents a fair fit of the whole dataset and the corresponding equation is Amplitude $=2.5 \times($ Rainfall -0.311$)$ where both Rainfall and Amplitude are in meters. The intercept of $311 \mathrm{~mm}$ corresponds to the minimum rainfall able to reach the aquifer. Some years depart strongly from this regression curve, for example 2010, with a $840 \mathrm{~mm}$ rainfall and a $0.35 \mathrm{~m}$ water level rise.

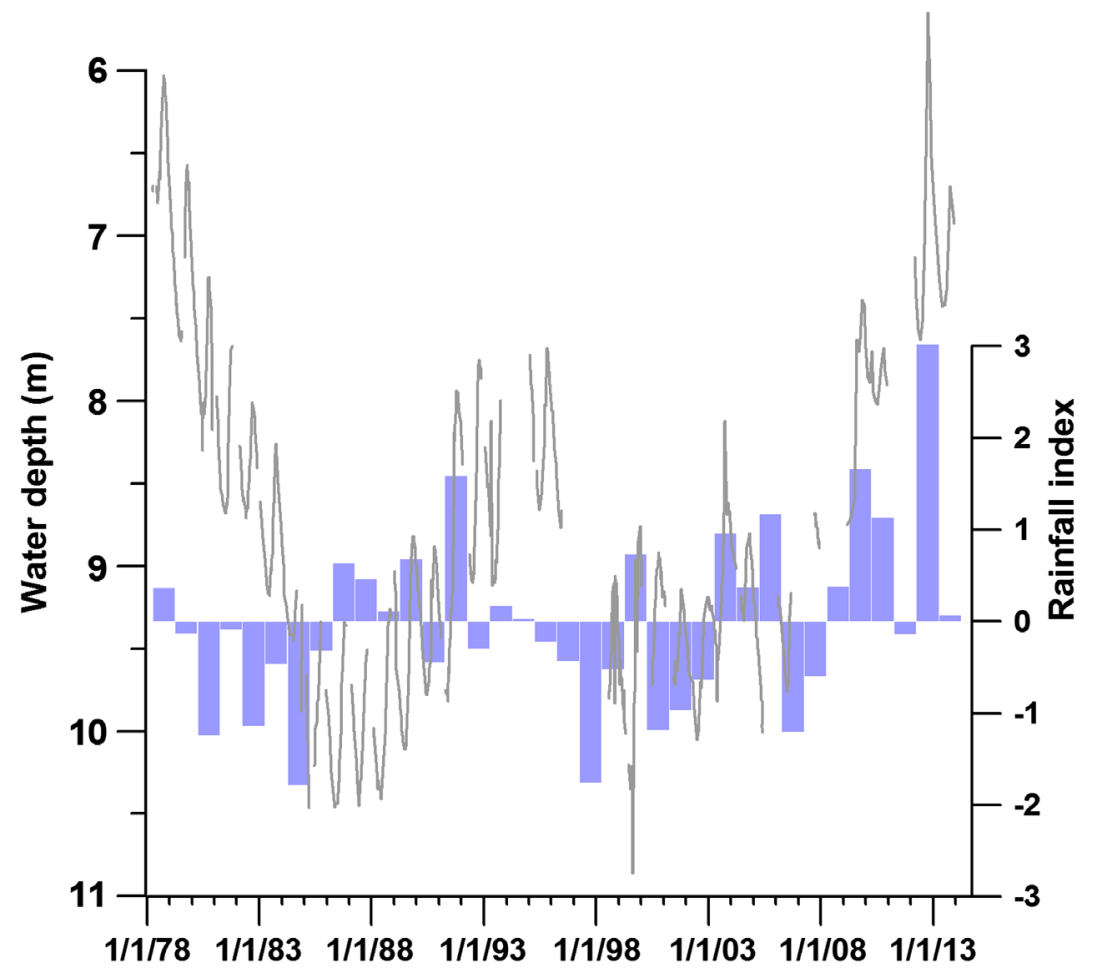

Figure 9. Comparison of the water level (in grey) and the rainfall index for the 1978-2013 period (in violin) at P-CIEH.

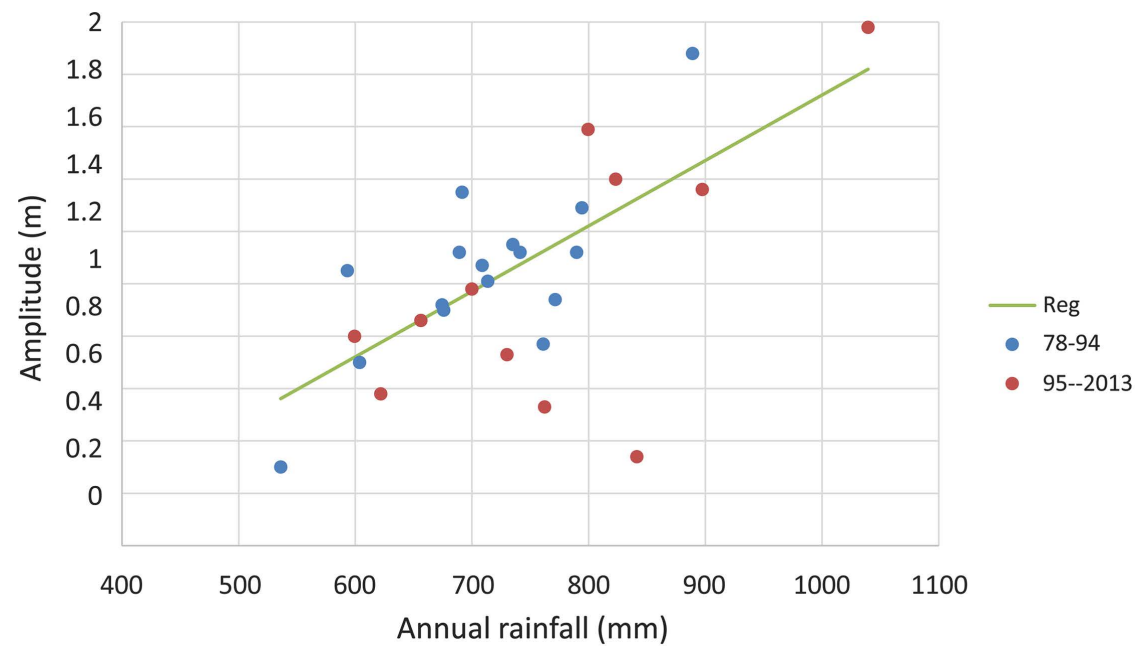

Figure 10. Relationship between the water level amplitude and rainfall at P-CIEH. The regression line is light green. 
The cross-correlogram between rainfall and the mean water level as well as the correlograms of these two variables were computed in order to detect a delayed response of the piezometric level to rainfall. There is strong correlation between water depth and past rainfall, reaching a maximum of 0.6 for a time lag of -4 yrs (Figure 11(a)). However, this result must be considered with care, since the autocorellation of the water level exhibits also strong correlation with past values (Figure 11(b)), reaching -0.8 for a time lag of -7 yrs which reflects the oscillatory component near the same period of 7 yrs visible on Figure 9. The rainfall
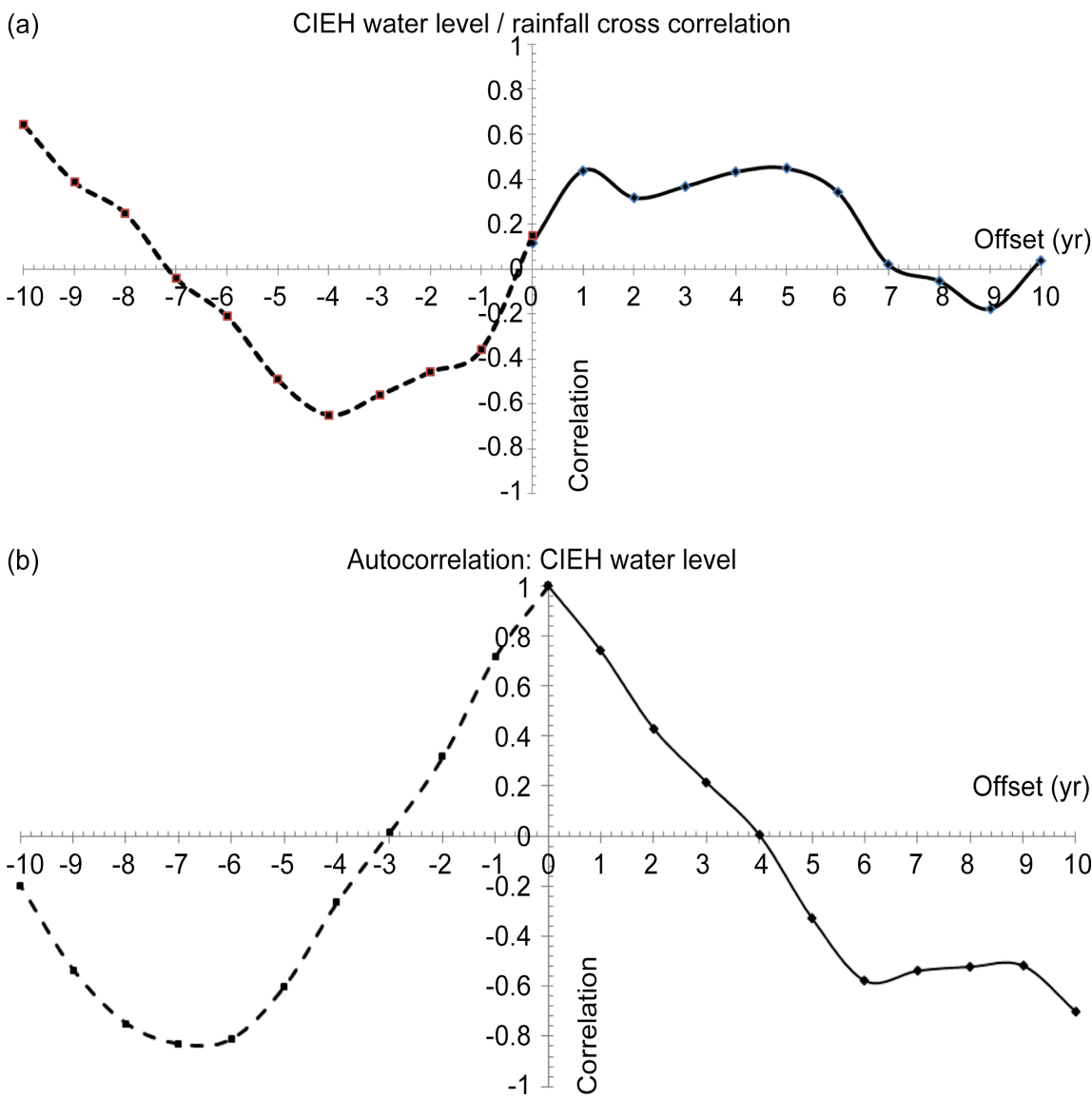

(c)

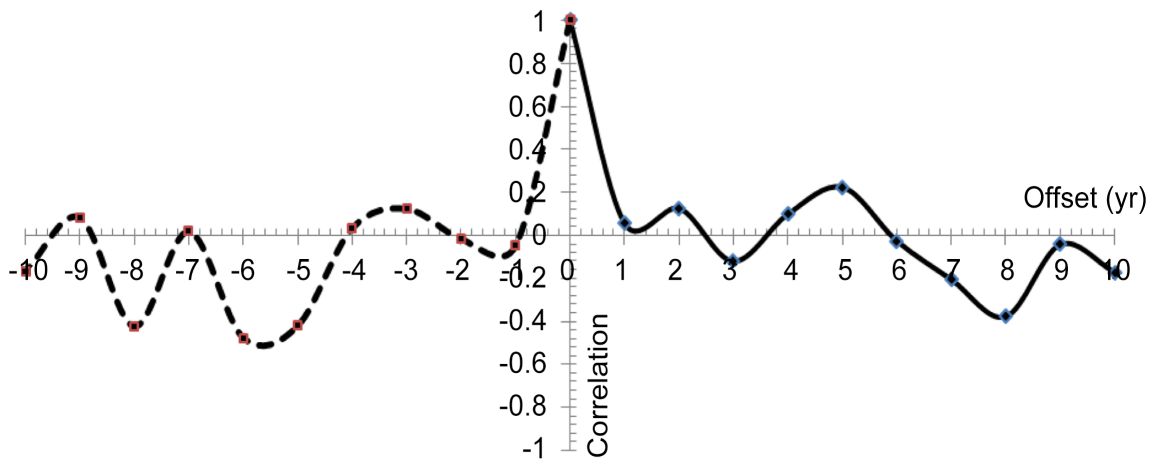

Figure 11. Correlation analysis of the relation between the mean annual water level at $\mathrm{P}-\mathrm{CIEH}$ and annual rainfall. 
correlogram (Figure 11(b)) shows that there is complete decorrelation between rainfalls of successive years. There might be secondary correlation peaks near 5 6 yrs time lag, they will not be discussed here. The conclusion of this section is that due to the oscillatory component in the water level signal, the correlation analysis cannot be used to assess its long term response to rain. The rainfall-water level relationship is therefore explored by numerical modeling in the next section.

\section{Numerical Modeling of Water Level Change in P-CIEH}

The models are designed in order to assess the different mechanisms controlling water level fluctuations in this borehole. Large uncertainties on hydraulic properties of the underground material near P-CIEH only allow using simplified models. The vertical 1d GARDENIA reservoir model [25] was used to model 10 piezometric records in Burkina Faso [31] and to model the decrease of water level in P-CIEH between 1978 and 1985 [23]. GARDENIA is a 3 reservoirs model with 8 free parameters, including the specific yield of the aquifer, a runoff coefficient, the thickness of the superficial reservoir, the emptying characteristic time of the middle reservoir and the initial levels in the three reservoirs. Beginning the simulation at the end of the dry season allows to assume that the two uppermost reservoirs are dry and that the level in the deepest reservoir is the water level at P-CIEH. This still leaves 5 free parameters which implies a large degree of equifinality. Moreover, GARDENIA cannot take into account lateral horizontal transfers induced by infiltration of water at the dam\#3 lake or by hydraulic gradients induced by the piezometric depression around P-CIEH. This model was used to extend the results obtained for the 1978-1985 period [23] to the whole P-CIEH record.

A 2d Modflow model was built along a NS cross-section including P-CIEH. This cross-section is perpendicular to the elongation of the series of EW trending reservoirs and wet areas from which infiltration occurs. This second model enables us to discuss the flow infiltrating from the dam\#3 lake and the convergent flow toward the piezometric depression near P-CIEH. The setup of a $2 \mathrm{~d}$ Modflow model requires a large number of parameters for the underground medium which are not available for the surrounding of P-CIEH. Therefore, a standard basement aquifer stratification is adopted and kept for all simulations. It consists of $20 \mathrm{~m}$ of saprolites of hydraulic conductivity $10^{-6} \mathrm{~m} / \mathrm{s}$ overlying a 10 $\mathrm{m}$ thick layer with a $10^{-5} \mathrm{~m} / \mathrm{s}$ hydraulic conductivity and $30 \mathrm{~m}$ of low permeability granite with an assumed $10^{-7} \mathrm{~m} / \mathrm{s}$ hydraulic conductivity (see section 2.1 ). Lateral flow in the aquifer is controlled by its transmissivity which is $1.2 \times 10^{-4}$ $\mathrm{m}^{2} / \mathrm{s}$, similar to the one used in the interpretation of the water table maps (see section 4.3.2). The model is forced by infiltration of a constant part of rainfall during the rainy season, between June and September. Reduced infiltration is assumed in the area of the piezometric depression. Water is extracted from the aquifer at a constant rate during the whole year. Three parameters only are ad- 
justed in the model: the ratio of infiltration over total rainfall, the constant water extraction, and the infiltration reduction over the piezometric low. Since the Modflow 2d model oversimplifies the infiltration mechanism, the details of annual water level fluctuations cannot be reproduced and the water level amplitude only can be compared with data. The specific yield is a free parameter within the $1 \%-15 \%$ range proposed for basement aquifers [16]. The value of $5 \%$ proposed for the Ouagadougou region [15] is adopted here. In Modflow, the water level change is the ratio between the amount of infiltrated water and the specific yield. Therefore, the model can be easily adapted to other specific yield values by changing the ratio of infiltration over rainfall. The length of the modelled area is $2500 \mathrm{~m}$. After having checked that the response to yearly water level changes in the dam\#3 lake were of few $\mathrm{cm}$ amplitude, the hydraulic head at the northern limit of the model is fixed to the mean annual water level in the reservoir. A fixed head boundary condition corresponding to the mean of the Mai 2013 and Oct. 2014 water levels is adopted as a constant head boundary condition at the southern end of the model. The initial water level in the modeled area is obtained by subtracting $1 \mathrm{~m}$ to the values of Figure 7(b) (May 2014), corresponding to the difference observed at $\mathrm{P}-\mathrm{CIEH}$ between the beginning of the record and May 2014.

The decrease of water level in P-CIEH between 1978 and 1990 is easily modelled with an infiltration of $22 \%$ of rainfall and a constant abstraction rate of 170 $\mathrm{mm} / \mathrm{yr}$, for the adopted $5 \%$ specific yield, assuming a zero infiltration on the area of the piezometric depression. A series of satisfactory results for the P-CIEH water level can also be obtained by increasing slightly the infiltration near the piezometric depression and decreasing the infiltration on the remaining of the profile. However, the modelled water level values fall below the observed ones after 1990. We found that it was impossible to reproduce the whole P-CIEH record with a single parameter set. This is best seen in Figure 12 after years 1992 and 2005. However, a decrease of 3\% of the water extraction after 1985 allowed to reproduce the whole P-CIEH record. Such a change could be associated to increased urbanization in the University area. With GARDENIA model it was also observed that the modelled water levels were below the observed ones, with any parameter combination able to reproduce the water level drop between 1978 and 1986. With the optimized Modflow model, the 2013-2014 water level amplitude is between $2 \mathrm{~m}$ and $2.5 \mathrm{~m}$ outside the piezometric depression and at a distance of more than $200 \mathrm{~m}$ from the reservoir, which approximately corresponds to observed values. The effect of the heightening of the spillway of the dam\#3 lake can be assessed by cancelling both the infiltration and the water uptake terms and starting with a flat water level between the two boundary conditions: the water level rises by $0.55 \mathrm{~m}$ during the modeled period and will continue to rise during the next 15 yrs. As indicated by the P-CIEH record the water level in the study area is not only controlled by climate, by also but by anthropic effects which was already noted in urban [32] or rural context [33]. 


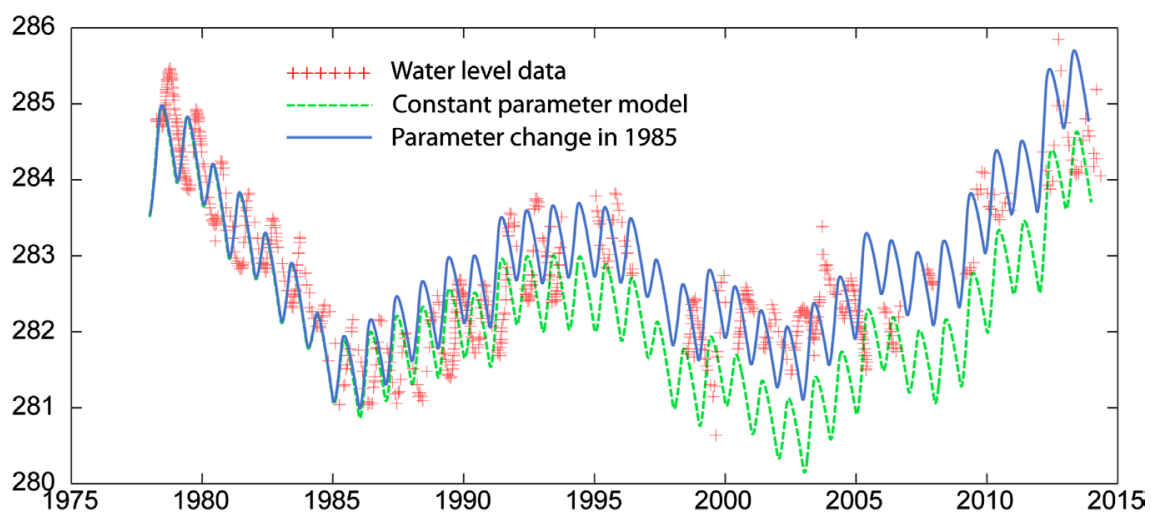

Figure 12. Modelling the water level signal at P-CIEH. The blue line accounts for a $3 \%$ decrease of the water uptake after 1985 while the green dotted line corresponds constant parameters.

\section{Discussion}

The model of the previous section relies on strong simplifications of the properties of the underground medium. However, as the horizontal flow is governed by the transmissivity of the aquifer, similar results would be obtained with different aquifer stratifications producing the same transmissivity. Moreover, the effect of changing the assumed specific yield of the aquifer can be easily computed since the model is constrained by water level fluctuations, which are the ratio of the infiltration flux to the specific yield. For a theoretical rainfall value lower than $260 \mathrm{~mm}$, the amount of infiltrating water during the rainy season is less than the water uptake during the same period and the annual water level amplitude is zero. This $260 \mathrm{~mm}$ value is similar to the intercept of $311 \mathrm{~mm}$ in the linear regression between the water amplitude at P-CIEH and rainfall. The amount of infiltrating water cannot be used to compute a runoff coefficient in the University area since water infiltrating in the superficial layers of soil can be extracted by vegetation before it reaches the aquifer. Similarly the uptake value is an underestimation of the ET component in the water budget. The piezometric depression around P-CIEH is obtained by canceling the infiltration term, while keeping a constant permeability. This piezometric depression probably results from combination of a reduced infiltration and a reduced permeability, which will also limit lateral transfers toward the piezometric depression. This low permeability zone might result from differences in the weathering profile resulting from initial heterogeneities in the granitic basement of the Ouagadougou city. These effects could be computed in a $2 \mathrm{~d}$ or $3 \mathrm{~d}$ model including the vadose zone. However this kind of model would require additional data which are lacking in the study area. Either $1 \mathrm{~d}$ or $2 \mathrm{~d}$ models require a slight change of parameters during the 80 s. Here a $3 \%$ decrease of the constant uptake is proposed, but the same effect would be achieved with a slight increase of the infiltration term. The GARDENIA model possesses 2 reservoirs between the surface and the aquifer. Therefore this effect cannot be a consequence of the oversimplification of water transfer toward the aquifer in the Modflow model. Moreover, in the Modflow 
model lateral flow toward the piezometric depression at P-CIEH are overestimated due to the assumption of a constant permeability stratification in the aquifer. This proves that the need for more water in the aquifer after the $80 \mathrm{~s}$ is not a consequence of neglecting lateral flow in GARDENIA. Therefore, it can be reasonably stated that the need of slight changes of the model parameters after the 80s results from changes in the surface properties in the University area.

\section{Conclusions}

Groundwater is available at a few meters depth in the investigated area. The Bangr Weogo park, which is a natural area could be explored for drinking water. Piezometric maps display large heterogeneities in water levels at the end of the dry season which are mostly smoothed at the end of the rainy season. The mean yearly water level amplitude in the piezometric network is $3 \mathrm{~m}$ with no striking difference between wells and boreholes and between the different land uses. During the 2013-2014 hydrologic year and except for the gardening area controlled by the dam\#3 water level and irrigation schedule, there was at least as much variability of the water table signal within a single land use than between the different land use sites. This constitutes a new result. P-CIEH is characterized by a water level drop of at least $3 \mathrm{~m}$ between 1978 and 1986 and an almost complete recovery starting at the beginning of the 2000s. The water level in $\mathrm{P}$-CIEH can be reproduced by a $2 \mathrm{~d}$ vertical Modflow model assuming a standard stratification for basement rock aquifers, a constant part of rainfall infiltrating during the rainy season, except in the area of the piezometric depression and a constant abstraction, presumably due to ET. However, the model requires a decrease of $3 \%$ of water abstraction after the 80 s, which could be attributed to building construction in the University area. Without this 3\% abstraction decrease, the present water level at P-CIEH would lie $1 \mathrm{~m}$ meter below the present one. Moreover a $0.55 \mathrm{~m}$ increase of the water level at P-CIEH results from the $1.2 \mathrm{~m}$ heightening of the spillway of the dam\#3 lake and it is expected that with constant climatic conditions, the water level will still increase during the next 15 yrs. Therefore, without the two anthropic effects discussed above, the P-CIEH water level would lie nearly $1.5 \mathrm{~m}$ below its 1978 level, which implies that groundwater resource would have not completely recovered from the drought effects since 1978.

Results of the present study suggest that P-CIEH is mostly controlled by climate with minor anthropic effects. Therefore, this piezometer could constitute a proxy for climate change impacts on the water resource in basement aquifers of West Africa. However, it cannot be considered as fully representative of the whole Ouagadougou city area since it presents the smallest annual water level amplitude and one of the lowest mean water level in the present survey. Moreover, it is located in a piezometric depression with a nearly $2 \mathrm{~m}$ amplitude either in May 2013 (end of the dry season) or in Oct. 2014 (maximum water level after the rainy season). Therefore, further investigations near P-CIEH are suggested 
including direct sampling, aquifer tests conducted after restoring hydraulic properties of boreholes and exploration geophysics.

\section{Acknowledgements}

A. H. Mouhouyouddine benefited from a PhD grant from the Islamic Bank of Development. Doctoral school SIBAGHE from Montpellier University is thanked for financial support during field work; National Meteorology of Burkina Faso, the BADOPLU and AMMA networks, the SIEREM database as well as Barry Moussa from IRD in Burkina Faso provided the climatology data. Advises from members of the PhD comity, namely, J.C. Maréchal, C. Leduc, L. Seguis and Y. Travi are acknowledged as well as help from H. Bancé during field work.

\section{References}

[1] Hulme, M. (2001) Climatic Perspectives on Sahelian Dessication: 1973-1998. Global Environmental Change, 11, 19-29. https://doi.org/10.1016/S0959-3780(00)00042-X

[2] Ardoin, S., Lubes-Niel, H., Servat, E., Dezetter, A., Boyer, J.-F., Mahé, G. and Paturel, J.-E. (2003) Analyse de la persistance de la sécheresse en Afrique de l'ouest: caractérisation de la situation de la décennie 1990. [Analysis of the Persistency of the West African Drought. Characterization of the 90s.] Hydrology of Die Mediterranean and Semiarid Regions, Montpellier, April 2003. Proc. Int. Ass. Hyd. Sci., 278, 223-228. (In French)

[3] Dewandel, B., Lachassagne, P. and Krishnamurthy, N.S. (2006) A Generalized 3-D Geological and Hydrogeological Conceptual Model of Granite Aquifers Controlled by Single or Multiphase Weathering. Journal of Hydrology, 330, 260-284. https://doi.org/10.1016/j.jhydrol.2006.03.026

[4] Dewandel, B., Lachassagne, P., Zaidi, F.K. and Chandra, S. (2011) A Conceptual Hydrodynamic Model of a Geological Discontinuity in Hard Rock Aquifers: Example of a Quartz Reef in Granitic Terrain in South India. Journal of Hydrology, 405, 474-487. https://doi.org/10.1016/j.jhydrol.2011.05.050

[5] Foster, S. (2012) Hard-Rock Aquifers in Tropical Regions: Using Science to Inform Development and Management Policy. Hydrogeology Journal, 20, 659-672. https://doi.org/10.1007/s10040-011-0828-9

[6] MacDonald, A.M., Boniir, H.C., Dochataigh, B.E.O. and Taylor, R.G. (2012) Quantitative Maps of Groundwater Resources in Africa. Environmental Research Letter, 7, Article ID: 024009. https://doi.org/10.1088/1748-9326/7/2/024009

[7] Vouillamoz, J.-M., Lawson, F.M.A. and Descloitres, M. (2015) Groundwater in Hard Rocks of Benin: Regional Storage and Buffer Capacity in the Face of Change. Journal of Hydrology, 520, 379-386. https://doi.org/10.1016/j.jhydrol.2014.11.024

[8] MacDonald, A.M., Calow, R.C., Macdonald, D.M.J., Darling, W.G. and Dochartaigh, B.É.Ó. (2009) What Impact Will Climate Change Have on Rural Water Supplies in Africa? Hydrological Sciences Journal, 54, 690-703. https://doi.org/10.1623/hysj.54.4.690

[9] Fournet, F., Meunier-Nikiema, A. and Salem, G. (2008) Ouagadougou (1850-2004). Une urbanisation différentiée, IRD, Marseille, France. https://doi.org/10.4000/books.irdeditions. 870

[10] UN-Habitat (2014) The State of African Cities 2014, Re-Imagining Sustainable Urban Transitions. UN-Habitat, Nairobi, Kenya, 273 p. 
[11] Castaing, C., Le Métour, J. and Billa, M. (2003) Notice explicative de la carte géologique et minière à $1 / 1000000$ ème du Burkina Faso. [Explanatory Note of the 1/1.000.000 Mining and Geological Map of Burkina Faso.] BUMIGEB, Ouagadougou. (In French)

[12] Chilton, P.J. and Foster, S. (1995) Hydrogeological Characterisation and Water-Supply Potentiel of Basement Aquifers in Tropical Africa. Hydrogeology Journal, 3, 36-49. https://doi.org/10.1007/s100400050061

[13] Taylor, R. and Howard, K. (2000) A Tectono-Geomorphic Model of the Hydrogeology of Deeply Weathered Crystalline Rock: Evidence from Uganda. Hydrogeology Journal, 8, 279-294. https://doi.org/10.1007/s100400000069

[14] Koïta, M. and Jourde, H. (2011) Hydrogeological Properties of Fractured Rocks (Granites, Metasediments and Volcanites) under the Humid Tropical Climate of West Africa. Advances in the Research of Aquatic Environment, 2, 3-10. https://doi.org/10.1007/978-3-642-24076-8_1

[15] Yameogo, S. (2008) Ressources en eau souterraine du centre urbain de Ouagadougou au Burkina Faso. [Groundwater Resources of the Urban Center of Ouagadougou, Burkina Faso.] Thèse, Université d'Avignon et des Pays de Vaucluse, 245 p. (In French)

[16] Lachassagne, P., Wyns, R. and Dewandel, B. (2011) The Fracture Permeability of Hard Rock Aquifers Is Due Neither to Tectonics, Nor to Unloading, But to Weathering Processes. Terra Nova, 23, 145-161. https://doi.org/10.1111/j.1365-3121.2011.00998.x

[17] Filippi, C., Milville, F. and Thiéy, D. (1990) Evaluation de la recharge naturelle des aquifères en climat Soudano-Sahélien par modélisation hydrologique globale: Application à dix sites au Burkina Faso. [Assessment of the Natural Recharge of Aquifer in a Soudano-Sahelian Climate Using Global Hydrological Modeling.] Hydrological Sciences Journal, 35, 29-48. (In French) https://doi.org/10.1080/02626669009492403

[18] Compaoré, G., Lachassagne, P., Pinter, T. and Travi, Y. (1997) Evaluation du stock d'eau des altérites: Expérimentation sur le site granitique de Sanon (Burkina Faso). [Assessment of the Water Volume Stored in Alterites. Experiments in the Granitic site of Sanon (Burkina Faso).] Proc. Int. Ass. Hydrol. Sci., 241, 37-46. (In French)

[19] IWACO (1986) Approvisionnement en eau potable de la ville de Ouagadougou (période 1985-2005), Etude hydrogéologique, rapport général, 29 p. [Water Supply in Ouagadougou. Hydrogeological Studies.] (In French)

[20] CIEH (1964) Alimentation en eau de Ouagadougou; Etudes hydrogéologiques. [Water Supply in Ouagadougou. Hydrogeological Studies.] Rapport du ministère des travaux publics de la construction et des transports de la république de Haute Volta (Burkina Faso), 66 p. (In French)

[21] Maréchal, J.C., Wyns, R. and Lachassagne, P. (2003) Anisotropie verticale de la perméabilité de l' horizon fissuré des aquifères de socle: concordance avec la structure géologique des profils d' altération. [Vertical Permeability Anisotropy in the Fissured Layer of Basement Aquifers: Comparison with the Geological Structure of Weathering Profiles.] C. $R$ Géoscience, 335, 451-460. (In French) https://doi.org/10.1016/S1631-0713(03)00082-8

[22] Maréchal, J.C., Dewandel, B. and Subrahmanyam, K. (2004) Use of Hydraulic Tests at Different Scales to Characterize Fracture Network Properties in the Weathered-Fractured Layer of a Hard Rock Aquifer. Water Resources Research, 40, 1-17. https://doi.org/10.1029/2004WR003137 
[23] Martin, J. and Thiéy, D. (1987) Analyse d'une longue série pièzomètrique au Burkina Faso. Etude de la variabilité climatique. [Analysis of a Long Piezometric Record in Burkina Faso. Effect of the Climatic Variability.] Hydrogéologie, 2, 137-146. (In French)

[24] Bacye (1986) Contribution à la mise en valeur des potentialités éco-touristiques de la ville de Ouagadougou: Projet de valorisation du Parc urbain Bangr-Weoogo. [Contribution to Enhancing the Eco-Touristic Opportunities in Burkina Faso. The Case of the Bangr Weogo Park.] EAMAU, Ouagadougou. (In French)

[25] Thiéry, D. (2003) Logiciel GARDENIA, Version 6.0. Guide d'utilisation, BRGM/RP 52832-FR, $102 \mathrm{p}$.

[26] Hargbauh, A.W. and McDonald, M.G. (1996a). User's Documentation for MODLFOW-96 an Update to the U.S. Geological Survey Finite Difference Groundwater Flow Model. Open-File Report 96-485, U.S. Geological Survey.

[27] Hargbauh, A.W. and McDonald, M.G. (1996b) Programmer's Documentation for MODFLOW-96 the U.S. Geological Survey Finite Difference Groundwater Flow Model. Open-File Report 96-486, U.S. Geological Survey.

[28] BURGEAP (1988) Essais de débits simplifies sur forages d'hydraulique villageoise: Notice Explicative. [Simplified Aquifer Tests in Village Water Supply. Explanatory Note.] CIEH, Ouagadougou. (In French)

[29] Van der Sommen, J.J. and Geirnaert, W. (1988) On the Continuity of Aquifer Systems on the Crystaline Basement of Burkina Faso. In: Simmers, I., Ed., Estimation of Natural Groundwater Recharge, NATO ASI Series, C222, Springer, Dordrecht, 29-45. https://doi.org/10.1007/978-94-015-7780-9_3

[30] Turcotte, D.L. and Schubert, G. (2014) Geodynamics. Cambridge University Press, Cambridge, $848 \mathrm{p}$.

[31] Thiéry, D. (1988) Analysis of Long-Duration Piezometric Records from Burkina Faso Used to Determine Aquifer Recharge. In: Simmers, I., Ed., Estimation of Natural Groundwater Recharge, NATO ASI Series, C222, Springer, Dordrecht, 477-489. https://doi.org/10.1007/978-94-015-7780-9_31

[32] Naik, P.K., Tambe, J.A., Dehury, B.N. and Tiwari, A.N. (2008) Impact of Urbanization on the Groundwater Regime in a Fast Growing City in Central India. Environmental Monitoring and Assessment, 146, 339-373. https://doi.org/10.1007/s10661-007-0084-6

[33] Leduc, C., Favreau, G. and Schroeter, P. (2001) Long-Term Rise in a Sahelian Water-Table: The Continental Terminal in South-West Niger. Journal of Hydrology, 243, 43-54. https://doi.org/10.1016/S0022-1694(00)00403-0 
Submit or recommend next manuscript to SCIRP and we will provide best service for you:

Accepting pre-submission inquiries through Email, Facebook, LinkedIn, Twitter, etc. A wide selection of journals (inclusive of 9 subjects, more than 200 journals)

Providing 24-hour high-quality service

User-friendly online submission system

Fair and swift peer-review system

Efficient typesetting and proofreading procedure

Display of the result of downloads and visits, as well as the number of cited articles Maximum dissemination of your research work

Submit your manuscript at: http://papersubmission.scirp.org/

Or contact jwarp@scirp.org 